\title{
Comparative Analysis of the Shear Bond Strength of Flowable Self-Adhering Resin-Composites Adhesive to Dentin with a Conventional Adhesive
}

\author{
Abdulmajeed Ali Asiri ${ }^{1}$, Rawaiz Khan ${ }^{2}$, Sultan Saeed Alzahrani ${ }^{1}$, Sajjad Haider ${ }^{3}$, , Salah Ud-Din Khan ${ }^{4}$, \\ Essa Ali Mousa Asiri ${ }^{1}$, Maha Fayez Alamri ${ }^{1}$, Ashfaq Ahmad ${ }^{5, *}$ and Muhammad Mubushar ${ }^{6}$ \\ 1 Jeddah Specialty Dental Center, Ministry of Health, Jeddah 21577, Saudi Arabia; \\ abalassiri@moh.gov.sa (A.A.A.); susaalzhrani@moh.gov.sa (S.S.A.); easiri@moh.gov.sa (E.A.M.A.); \\ maha.alamri@gmail.com (M.F.A.) \\ 2 Engineer Abdullah Bugshan Research Chair for Dental and Oral Rehabilitation, College of Dentistry, \\ King Saud University, Riyadh 11545, Saudi Arabia; krawaiz@ksu.edu.sa \\ 3 Department of Chemical Engineering, College of Engineering, King Saud University, P.O. Box 800, \\ Riyadh 11421, Saudi Arabia; shaider@ksu.edu.sa \\ 4 Sustainable EnergyTechnologies(SET) Center, College of Engineering, King Saud University, P.O. Box 800, \\ Riyadh 11421, Saudi Arabia; drskhan@ksu.edu.sa \\ 5 Department of Chemistry, College of Science, King Saud University Riyadh, P.O. Box 2455, \\ Riyadh 11451, Saudi Arabia \\ 6 Department of Plant Production, College of Food and Agriculture Sciences, King Saud University, \\ Riyadh 11451, Saudi Arabia; mubusharuaf@gmail.com \\ * Correspondence: aahmad1@ksu.edu.sa
}

Citation: Asiri, A.A.; Khan, R.; Alzahrani, S.S.; Haider, S.; Khan, S.U.-D.; Asiri, E.A.M.; Alamri, M.F.;

Ahmad, A.; Mubushar, M. Comparative Analysis of the Shear Bond Strength of Flowable Self-Adhering Resin-Composites Adhesive to Dentin with a Conventional Adhesive. Coatings 2021, 11, 273. https://doi.org/ 10.3390/coatings11030273

Academic Editor: William A. Brantley

Received: 18 January 2021

Accepted: 22 February 2021

Published: 25 February 2021

Publisher's Note: MDPI stays neutral with regard to jurisdictional claims in published maps and institutional affiliations.

Copyright: (c) 2021 by the authors. Licensee MDPI, Basel, Switzerland. This article is an open access article distributed under the terms and conditions of the Creative Commons Attribution (CC BY) license (https:/ / creativecommons.org/licenses/by/ $4.0 /)$.

\begin{abstract}
This study aimed to measure and compare the shear bond strength (SBS) of a self-adhering flowable resin composite to dentin with a conventional flowable composite, and evaluate the various modes of failure. Thirty human premolar teeth $(n=30)$ were randomly allocated to two groups (Group I: Vertise ${ }^{\mathrm{TM}}$ Flow; Group II: Filtek Ultimate + Single Bond Universal) of 15 specimens each, and SBS was measured for specimens from each group by applying a shear load using a universal testing machine (UTM). Modes of failure were observed with an optical microscope. An independentsamples T-test was performed to test Levene's assumption of homogeneity of variance across both groups, with the critical value set at 0.05 . The results revealed, that the self-adhering flowable composite (Group I: Vertise ${ }^{\mathrm{TM}}$ Flow) resulted in a lower shear bond strength compared with the conventional adhesive system composite (Group II: Filtek Ultimate + Single Bond Universal). Moreover, group I predominantly exhibited non-cohesive failure, which reflects poor bonding to dentin. On the other hand, Group II showed mixed failure for most of the samples, which demonstrated strong adhesive bonding. Therefore, it could be concluded that the self-adhering flowable resin composite (Group I) results in lower SBS to dentin compared with a conventional adhesive system.
\end{abstract}

Keywords: shear bond strength; dental adhesives; flowable resin composites; self-adhering composites

\section{Introduction}

The development of restorative materials that show adhesion to tooth structure is an interesting area of research. The lack of adherence of restorative materials to the tooth structure may lead to several problems, such as secondary caries, marginal leakage (infiltration of fluids, bacteria, and ions into the gaps between restoration and cavity walls) [1], and post-operative sensitivity. Adhesion to dentin is more difficult compared to enamel [2,3]. This lack of adhesion to dentin is attributed to its organic composition and the fluid that is present in the dentinal tubules. In contrast, the porosity and collagen in the tubules may help to make adhesion stronger [4]. Currently, flowable restorative composites (nano-fillers added to low viscosity monomers) are ideal for many applications, 
such as pit-and-fissure sealant, small Class III and V restorations, enamel flaws, and incisal edge repairs [5]. Flowable composites generally result in higher shrinkage and lower elastic modulus (due to a lesser filler content) than conventional non-flowable resin systems [6]. The interfacial shrinkage stresses between dental tissue and composites indicate the potential to increase the marginal leakage. Three-step conventional adhesive systems (etch + primer + bond) may result in high resin to dentin adhesion, however, factors such as excessive etching may influence the performance due to the possibility that the resin monomers may not be able to penetrate the open dentinal tubules. In addition, there is the possibility of collagen collapse on air drying after etching [7]. A huge number of new adhesive systems have emerged (universal or multi-mode), and different operative techniques for each group of materials have been introduced [8-10]. As a result, it has become a challenge for dentists to choose an adhesive system for routine use at the clinic. Therefore, the practitioners need to be aware of the physical and chemical characteristics of these materials and their association with structures, to select and use them correctly.

The bonding between the restorative material and tooth substrate greatly influences the mechanical, biological, and aesthetic properties. It has been always a great challenge to bond resin-based composites to dentin in comparison to enamel bonding [11,12]. The bond strength of resin composites to dentin could be assessed via numerous techniques like flexural strength and tensile strength $[4,13]$. However, shear bond strength (SBS) is considered a facile, and commonly adopted method for measuring the bond strength of restorative materials $[14,15]$. So far, very little literature is available on the SBS of selfadhering flowable composites. Therefore, in the current study, we have adopted the SBS method to compare the adhesion properties of a conventional adhesive system composite with that of self-adhering resin composite.

Generally, self-etch adhesive bonding methods are being used as an alternative to conventional adhesive system resin composites, mainly due to the handling difficulties of the later [12,15-17]. However, besides the clinical advantages associated with these systems, their etching potential and bonding performance still need to be tested under various clinical circumstances $[14,18,19]$. Therefore, there has been increased interest in self-adhering flowable composite technology. Recently, Rengo et al. [20] showed that a self-adhering flowable resin composite resulted in higher microleakage in dentin interfaces as compared with enamel interfaces. Moreover, they observed that the etching of dentin using phosphoric acid reduced the sealing performance when a self-adhering flowable resin composite was applied in class $\mathrm{V}$ cavities. The etching was carried out to open dentinal tubules so that the adhesive could penetrate to the dentinal tubules. So by etching, the dentinal tubules were opened to enhance penetration of the adhesive. This will not only block the micro-leakage channels but also increase interlocking, and subsequently improve the shear bond strength.

In order to simplify the procedure, the manufacturers have launched adhesive systems that combine the primer and adhesive in a one-step. This new class of flowable composites is called "self-adhering resin composites" (SRCs). They do not require a separate acid conditioning step and moist post-rinse control. They are considered simplified adhesive materials and offer some advantages over conventional etch-and-rinse systems, such as reduction of postoperative sensitivity, prevention of procedural errors related to clinical application of conventional bonding agents (such as over-drying and over-wetting), and reduction of chair time [18,21,22]. Another advantage is that infiltration of adhesive resin tends to occur simultaneously with the self-etch process [23]. As the rinsing and drying steps are excluded by the use of SRCs, therefore, the chances of cavity contamination, over-drying, and overwetting issues are reduced [18].

These new SRCs have been proposed as an adhesive-free restorative material indicated for the restoration of small class I cavities, class V cavities, and noncarious cervical lesions, as well as for lining in class I and II restorations [24]. Despite the ease of clinical use and other advantages of these SRCs, their durability and clinical service are still a matter of 
great concern for many dental practitioners [25]. Limited studies are available about their physical and mechanical properties [21,26,27].

This study aimed to evaluate the SBS of a self-adhering flowable composite and a conventional adhesive system composite to natural teeth dentin and the mode of failure of these two components, to evaluate their adhesion properties and their clinical performance.

\section{Materials and Methods}

\subsection{Materials}

The materials used in this study are summarized here along with the supplier's details. The information regarding flowable composites used in this study is given in Table 1.

Table 1. Materials used in the current study.

\begin{tabular}{|c|c|c|c|c|}
\hline $\begin{array}{l}\text { Group } \\
\text { Name }\end{array}$ & $\begin{array}{l}\text { Product } \\
\text { Name }\end{array}$ & Manufacturer & Composition & Instructions for Use \\
\hline Group I & $\begin{array}{l}\text { Vertise } \\
\text { Flow }\end{array}$ & $\begin{array}{l}\text { Kerr, } \\
\text { Orange, } \\
\text { CA, USA }\end{array}$ & $\begin{array}{l}\text { GPDM adhesive and methacrylate } \\
\text { co-monomers, monomer, prepolymerized } \\
\text { filler containing barium glass filler, } \\
\text { nano-sized colloidal silica, nano-sized } \\
\text { Ybf3 (70 wt. } \% \text { ) }\end{array}$ & $\begin{array}{c}\text { Brush a thin layer }(<0.5 \mathrm{~mm}) \text { of Vertise } \\
\text { Flow for } 15-20 \mathrm{~s} \text {, light cure for } 20 \mathrm{~s} \text {. Build } \\
\text { additional layers }(2 \mathrm{~mm} \text { or less }) \text { then light } \\
\text { cure for } 20 \mathrm{~s}\end{array}$ \\
\hline \multirow{2}{*}{ Group II } & $\begin{array}{l}\text { Filtek } \\
\text { Ultimate } \\
\text { Flow }\end{array}$ & $\begin{array}{l}\text { 3M ESPE, St. } \\
\text { Paul, MN, } \\
\text { USA }\end{array}$ & $\begin{array}{c}\text { Bis-GMA, TEGDMA, and procrylat resins, } \\
\text { Ybf3 filler, zirconia/silica cluster filler, } \\
\text { silica filler }\end{array}$ & $\begin{array}{l}\text { Place the composite into the cavity }(2 \mathrm{~mm}) \\
\text { Light cure for } 20 \mathrm{~s}\end{array}$ \\
\hline & $\begin{array}{l}\text { Single Bond } \\
\text { Universal }\end{array}$ & $\begin{array}{l}\text { 3M ESPE, St. } \\
\text { Paul, MN, } \\
\text { USA }\end{array}$ & $\begin{array}{c}\text { MDP phosphate monomer, } \\
\text { dimethacrylate resins vitrebond } \\
\text { copolymer, HEMA, filler, ethanol, water, } \\
\text { initiators, silane }\end{array}$ & $\begin{array}{l}\text { Apply a single coat of the adhesive to the } \\
\text { required area on tooth by rubbing for } 20 \mathrm{~s} \text {; } \\
\text { direct a gentle stream of air over the } \\
\text { material for } 5 \mathrm{~s} \text { then LED light cure }\end{array}$ \\
\hline
\end{tabular}

Bis-GMA: bisphenol-aglycidylmethacrylate; GPDM: glycero-phosphate dimethacrylate; TEGDMA: triethylene glycol dimethacrylate; Ybf3: Ytterbium Fluoride; MDP: Methacryloxydecyl dihydrogen phosphate; HEMA: 2 hydroxyethyl methacrylate.

\subsection{Methods}

Thirty human premolar teeth were used in the study. Following extraction, teeth were thoroughly cleaned with pumice to eliminate any surface debris, and were kept in $0.1 \%$ thymol solution at room temperature before the experiment. The teeth were then inspected under magnification to ensure that they do not have cracks, fractures, or flaws (step 1). The teeth were then embedded in self-cure acrylic resin (which cures itself) in a plastic mold $\left(2 \times 2\right.$ inch $\left.^{2}\right)$.

To eliminate the coronal enamel, a low-speed cutting machine (Isomet, Buehler, Ltd., Evanston, IL, USA) was used for sectioning all the teeth (step 2). Subsequently, the specimens were embedded in self-cure acrylic resin in a plastic mold. To obtain uniformity, the embedded teeth's occlusal surface and acrylic resin were kept at the same level in the mold. The specimen's surface was then wet ground with various silicon carbide papers (320, 400, 600 grit) to further smooth the dentinal surface. All the specimen's surfaces were inspected with a dissecting microscope to confirm the complete removal of enamel fragments (step 3). The specimens were then stored in a water container in an incubator at $37^{\circ} \mathrm{C}$ for $24 \mathrm{~h}$ before bonding. The specimens were randomly segregated into two groups of 15 specimens (step 4) each, and named Group I: Vertise ${ }^{\mathrm{TM}}$ Flow (Kerr, CA, USA) and Group II: Filtek Ultimate + Single Bond Universal. The single bond universal liner was applied (step 5), rubbed for $20 \mathrm{~s}$, streamed gently with air to ensure uniform distribution and light-cured (step 6).

A cylindrical polyvinyl siloxane putty mold with $3.0 \mathrm{~mm} \times 3.0 \mathrm{~mm}$ (height $(\mathrm{H}) \times$ diameter (D)) dimensions was positioned on the surface of the dentin, and the resin composite was filled in the mold (step 7,8) and irradiated for the $20 \mathrm{~s}$ using a LED curing unit (Elipar Free Light II; 3M/ESPE, St. Paul, MN, USA, $1200 \mathrm{~mW} / \mathrm{cm}^{2}$ ). The polyvinyl siloxane putty was removed with a sharp blade (step 9,10), and the specimens were examined for defects 
under a light stereomicroscope at $10 \times$ magnification. The samples were then kept in $100 \%$ relative humidity for $24 \mathrm{~h}$ at $37^{\circ} \mathrm{C}$. Figure 1 shows a stepwise scheme for the preparation of the sample.
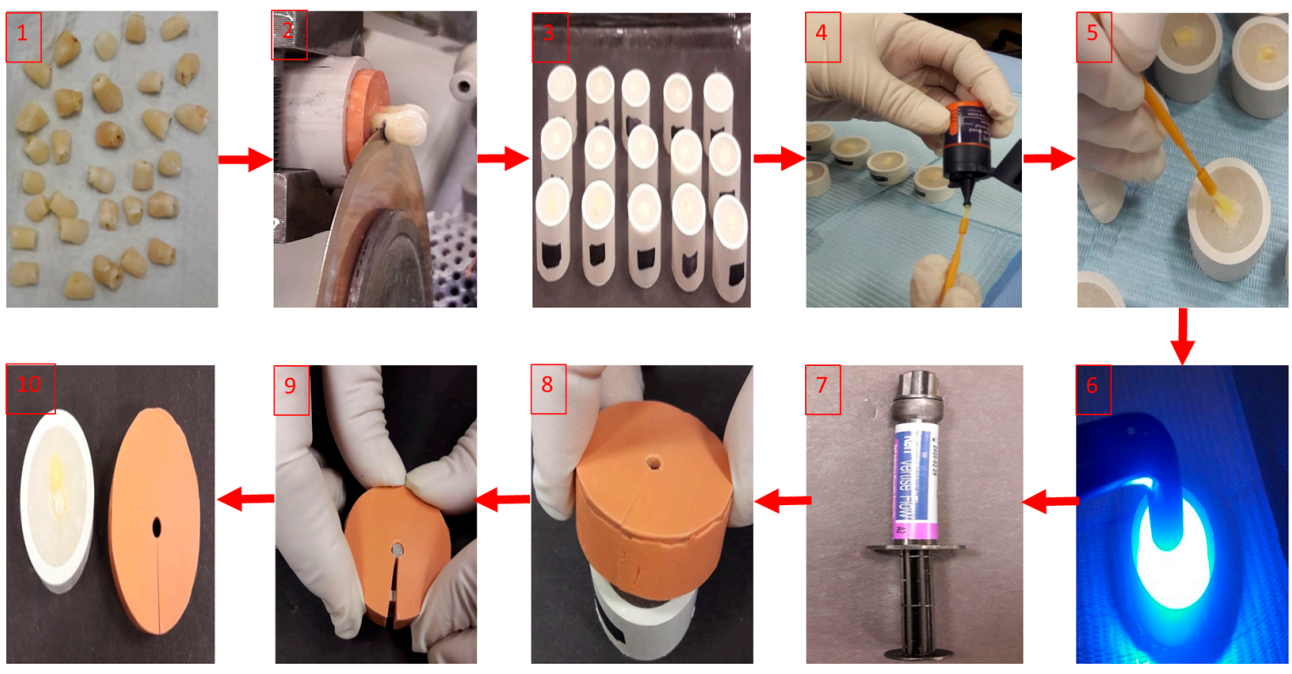

Figure 1. Stepwise flow diagram of sample preparation: (1): teeth inspection for defects; (2) removal of enamel to expose dentin by sectioning the teeth; (3) embedding teeth in resin in a plastic mold ( $2 \times 2$ inch $^{2}$ ) and surface smoothening; $(4,5)$ applying adhesive to dentin; (6) irradiation of adhesive; $(7)$ flowable composite packing; (8) polyvinyl siloxane putty with $3.0 \mathrm{~mm} \times 3.0 \mathrm{~mm}(\mathrm{H} \times \mathrm{D})$ dimensions positioned on dentin; (9) filling of flowable composite for build-up; (10) removal of mold.

\subsection{Shear Bond Testing}

Specimens were mounted on the universal testing machine (Instron 5965) and the shear force was applied at a crosshead speed of $1.0 \mathrm{~mm} / \mathrm{min}$ through a knife-edge blade using a $5 \mathrm{kN}$ load cell. SBS was measured in MPa by dividing the peak load at failure with the specimen surface area.

For statistical analysis, an independent samples $t$-test was performed to test Levene's assumption of homogeneity of variance across both groups, with the critical value set at 0.05 , and using SPSS.

The samples mounted on the SBS testing machine are shown in Figure $2 \mathrm{~b}$.
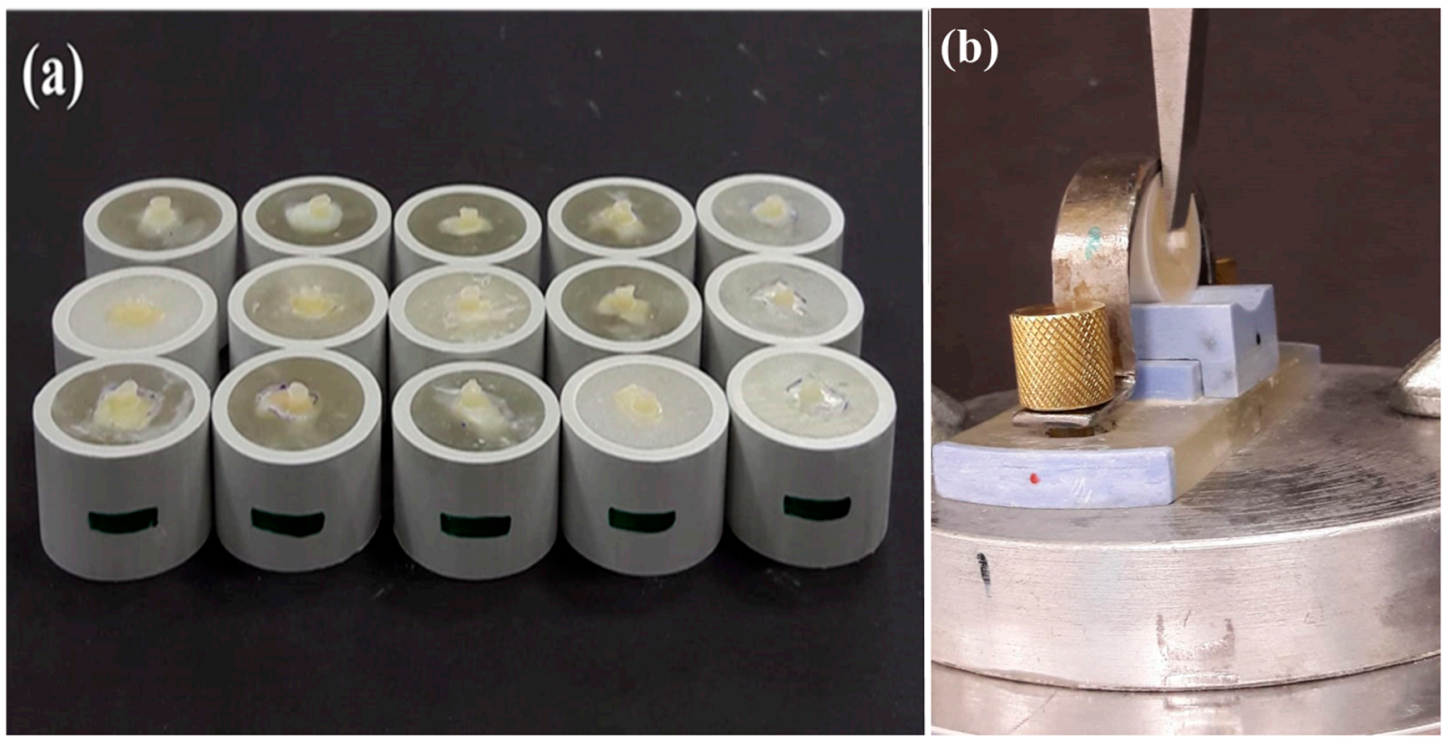

Figure 2. (a) Prepared samples bonded to dentin. (b) Sample mounted for shear bond strength. 


\section{Results}

3.1. Shear Bond Strength Group I and Group II

The obtained results for each specimen of Group I are depicted in Table 2. The mean SBS demonstrated by Group I was $17.3 \mathrm{MPa}$ at a maximum mean load of $122 \mathrm{~N}$.

Table 2. Shear bond strength for Group I specimens $(n=15)$.

\begin{tabular}{ccc}
\hline Sample No. & Maximum Load (N) & $\begin{array}{c}\text { Shear Bond Stress at Maximum Load } \\
\mathbf{( M P a})\end{array}$ \\
\hline 1 & 139.9 & 19.8 \\
2 & 123.9 & 17.5 \\
3 & 137.2 & 19.4 \\
4 & 117.1 & 16.6 \\
5 & 136.9 & 19.4 \\
6 & 120.5 & 17.0 \\
7 & 114.1 & 16.1 \\
8 & 125.3 & 17.7 \\
9 & 133.9 & 18.9 \\
10 & 120.8 & 17.1 \\
11 & 111.9 & 15.8 \\
12 & 112.6 & 15.9 \\
13 & 111.5 & 15.8 \\
14 & 105.4 & 14.9 \\
15 & 119.1 & 16.8 \\
Mean & 122.0 & 17.3 \\
Standard Deviation (SD) & 10.7 & 1.5 \\
\hline
\end{tabular}

Similarly, the results obtained for each specimen of Group II are depicted in Table 3. The mean SBS demonstrated by Group II was $25.2 \mathrm{MPa}$ at a mean maximum load of $178.2 \mathrm{~N}$.

Table 3. Shear bond strength for Group II specimens $(n=15)$.

\begin{tabular}{ccc}
\hline Sample No. & $\begin{array}{c}\text { Maximum Load } \\
\mathbf{( N )}\end{array}$ & $\begin{array}{c}\text { Shear Bond Stress at Maximum Load } \\
(\mathbf{M P a})\end{array}$ \\
\hline 1 & 168.7 & 23.9 \\
2 & 167.1 & 23.6 \\
3 & 191.5 & 27.1 \\
4 & 194.6 & 27.5 \\
5 & 149.5 & 21.2 \\
6 & 197.2 & 27.9 \\
7 & 205.1 & 29.0 \\
8 & 143.5 & 20.3 \\
9 & 191.1 & 27.0 \\
10 & 177.1 & 25.0 \\
11 & 177.8 & 25.1 \\
12 & 170.2 & 24.1 \\
13 & 192.7 & 27.3 \\
14 & 188.4 & 26.7 \\
15 & 158.9 & 22.5 \\
Mean & 178.2 & 25.2 \\
Standard Deviation & 18.3 & 2.6 \\
\hline
\end{tabular}

The results of the Levene's test for equality of variances in the SBS of Group I and Group II are illustrated in Figure 3. The obtained results revealed that the mean SBS of Group II was statistically greater than that of Group I (critical-value $<0.05$ ). Therefore, the null hypothesis was rejected. 


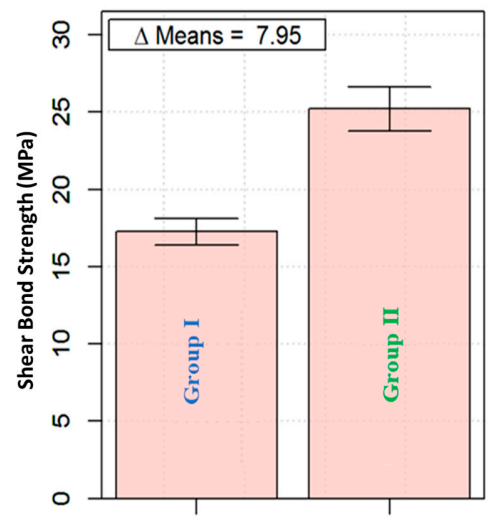

Figure 3. Statistical comparison of mean shear bond strength (SBS) of Group I and Group II with standard error $(\mathrm{SD}= \pm 2.5)$.

\subsection{Modes of Failure}

Figures 4 and 5 present the fracture patterns for each sample $(n=15)$ for both Group I and Group II, respectively. Non-cohesive failure was the most dominant mode of failure in Group I. All the samples exhibited non-cohesive failure in Group I, except S-3 (Figure 4), which resulted in cohesive failure. On the other hand, mostly cohesive failure was observed for Group II. Adhesive failure was observed for four samples S-2, S-7, S-9, and S-10 (Figure 5) in Group II only, the rest of the 12 (S-1 to 6, S-8, and S-11 to S-15) samples exhibited cohesive failure.
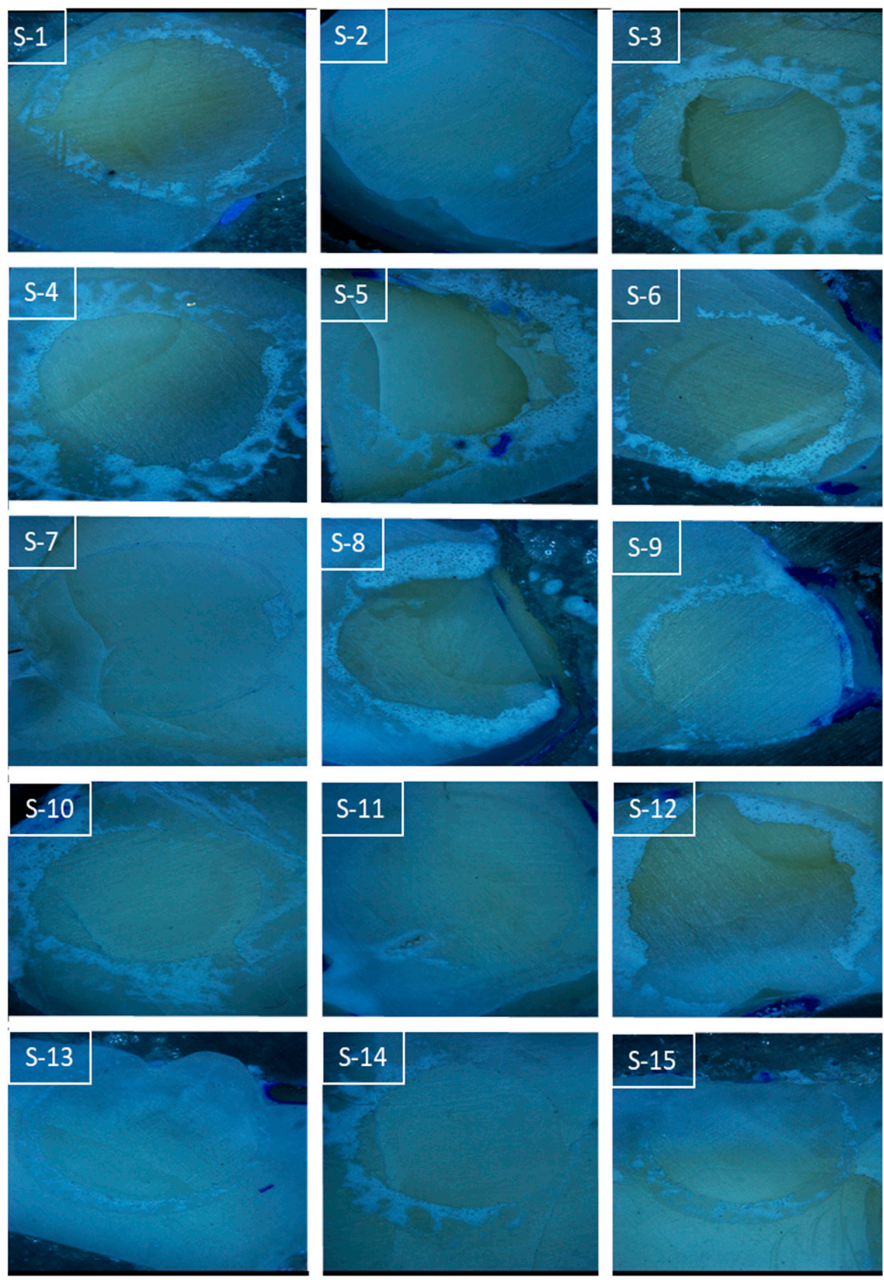

Figure 4. Microscopic analysis of the modes of failure $n=15$ (Group I). 

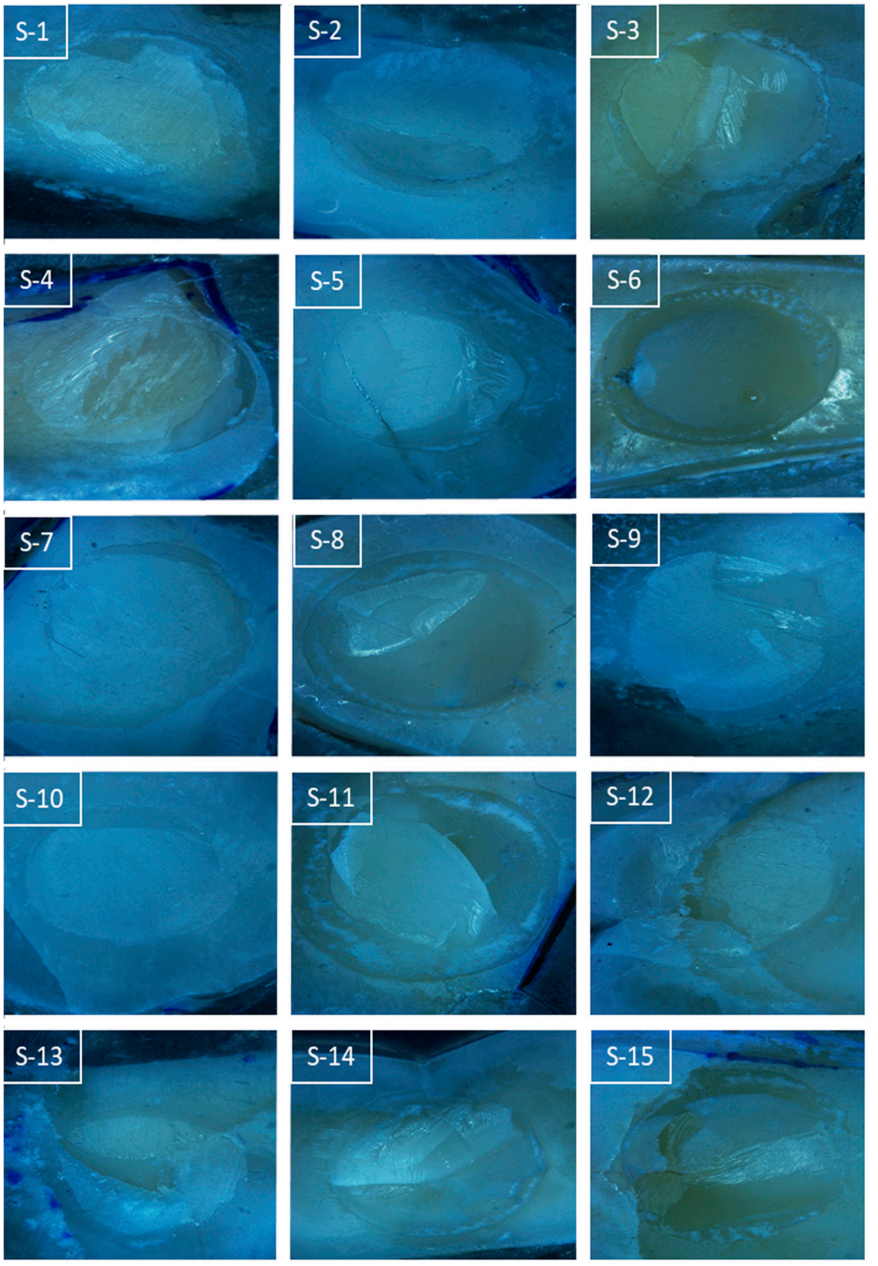

Figure 5. Microscopic analysis of the modes of failure $n=15$ (Group II).

\section{Discussion}

It was assumed from the literature that a minimum bond strength of 17-20 Mpa is sufficient to withstand the contraction forces of resin composite materials for enamel and dentin. Clinical experience indicates that this bond strength is adequate for the effective restoration of resin $[28,29]$. The present study revealed that the mean SBS of conventional flowable resin composite (Filtek Ultimate) is considerably greater than that of SRC (Vertise ${ }^{\mathrm{TM}}$ Flow). Therefore, the first null hypothesis was rejected. The bonding of resin composites to enamel and dentin is carried out by removing minerals from dental hard tissue and replacing it with resin monomers, which upon polymerization create micromechanical interlocking in the porosities [30]. The bonding process of Vertise ${ }^{\mathrm{TM}}$ Flow depends on the monomer adhesive (GPDM), because due to the presence of the phosphate group, it promotes etching and develops a chemical interaction with dental specimens [31]. In the current study, the lower bond strength of Vertise Flow may be associated with its limited ability to demineralize and infiltrate dentin substrate, which may result in poor micromechanical interlocking, ineffective sealing of dentinal tubules, and poor wetting of dentin collagen fibrils. The self-adhering resin composite should be able to quickly interact with dentin and acquire optimal wetting characteristics in a short period of time [32-34]. The bond strength of SRCs can be partially related to their chemical interaction with dentin hydroxyapatite [35].

As per the manufacturer, there are two ways by which Vertise Flow interacts with tooth surfaces. The first mechanism involves the chemical interaction of calcium ions in the tooth with the functional phosphate groups in the GPDM monomers (inside the resin), whereas the second bonding mechanism occurs as a result of micromechanical etching 
of the tooth caused by the low $\mathrm{pH}(\mathrm{pH}=1.9)$ of the resin material, which is analogous to that of numerous self-etching materials [36]. The SBS of Vertise ${ }^{\mathrm{TM}}$ Flow has been studied by other researchers, with and without using an adhesive. Their results revealed that, with an adhesive system, Vertise ${ }^{\mathrm{TM}}$ Flow had greater bond strength values compared to its individual use. They also found that the SBS of the conventional flowable composite, Filtek Ultimate Flow, was higher than that of a self-adhering resin composite (Vertise ${ }^{\mathrm{TM}}$ Flow), which is in line with our current study [36]. The high SBS of Filtek Ultimate could be attributed to the wetting properties of the adhesives to dentin. Previous studies have reported that optimum bonding can be achieved by having specific wetting properties of the adhesive resin similar to the conditioned dentin [37,38]. Similarly to our study, different in vitro studies revealed that Vertise ${ }^{\mathrm{TM}}$ Flow displayed lower SBS values than all-in-one adhesive, [39] self-etch (two-step), and etch and rinse adhesive systems [40]. From the literature, the minimum bond strength to withstand the contraction forces of resin composite materials for enamel and dentin is 17-20 Mpa [28,29]. In the current study, Vertise $^{\mathrm{TM}}$ Flow demonstrated acceptable SBS value for clinical performance. However, the value was almost at the minimum threshold value. On the other hand, Filtek Ultimate resulted in a considerably higher SBS value ( $25 \mathrm{Mpa}$ ) than that of the minimum threshold value required for acceptable clinical performance $(17 \mathrm{Mpa})$. Therefore, the conventional flowable composite (Filtek Ultimate) is expected to have better clinical performance.

It was observed from microscopic analysis (Figures 4 and 5) that the non-cohesive failure mode was predominantly observed in Group I. On the other hand, the most cohesive failures occurred in Group II, which may be attributed to the higher bond strength, demonstrating an efficient bonding [41]. In addition, due to the high number of cohesive failures, it could be inferred that the stress distribution was balanced during the mechanical testing of bond strength [42]. Sometimes, the stresses are not homogeneously distributed, either due to the uneven surfaces or due to the large filler size in the adhesive, which may lead to adhesive failure.

Shear bond tests are tensile stresses that cause de-bonding. The results may vary from different studies because the stress distribution at the interface is very heterogeneous. In addition, it is noteworthy to mention that the position and configuration of the loading device greatly affect the stress distribution at the bonded interface, and as a result may cause variation in the results. The force that causes de-bonding of the specimen increases with the increasing distance of the loading device from the interface, due to the bending moment of the cylindrical specimen. Therefore, to avoid variation in the results and keep consistency, we tried our best to keep the position of the loading device accurate during the course of testing. However, SBS results obtained for a specific material from different studies may not be associated due to variation in the bonding substrate, specimen preparation, storage conditions, and loading method [43].

\section{Conclusions}

Within the limitations of this study, the self-adhering flowable composite Vertise ${ }^{\mathrm{TM}}$ Flow resulted in the lowest SBS compared with the conventional flowable resin composite (Filtek Ultimate), which showed the greater SBS. Therefore, reducing the bonding procedures (avoiding etch and rinsing steps), reduces the bond strength. In addition, Vertise ${ }^{\mathrm{TM}}$ Flow predominantly exhibited non-cohesive failure, which reflects a poor bonding to dentin. Moreover, the low SBS of Vertise ${ }^{\mathrm{TM}}$ shows its limited ability to interact with dentin, demineralize it, and infiltrate into the dentin substrate, which may result in poor micromechanical interlocking, ineffective sealing of dentin tubules, and poor wetting of dentin collagen fibrils. On the other hand, the conventional flowable composite (Filtek Ultimate) showed mixed failure for most of the samples, which demonstrates its favorable wetting properties (due to single bond universal) and good chemical interaction with dentin, and subsequently resulted in strong adhesive bonding. Further clinical trials are required to evaluate the data acquired, in the laboratory on the new self-adhering flowable composites, 
and under clinical situations in dentistry. The in vitro and clinical evaluation will help to improve the performance of Vertise ${ }^{\mathrm{TM}}$ Flow for the long-term application in restorations.

Author Contributions: Conceptualization, A.A.A. and S.S.A.; methodology, A.A.A. and E.A.M.A.; software, M.M.; validation, M.M., R.K., and A.A.; formal analysis, M.F.A. and A.A.A.; investigation, S.S.A. and M.F.A.; resources, A.A.A.; data curation, A.A.A., S.S.A.; writing-A.A.A. and S.H.; draft preparation, S.U.-D.K.; writing-review and editing, R.K., A.A., and S.U.-D.K.; visualization, S.S.A.; supervision, S.H.; project administration, M.F.A. and S.U.-D.K.; funding acquisition, A.A. and S.U.D.K. All authors have read and agreed to the published version of the manuscript.

Funding: This research was funded by the Deanship of Scientific Research at King Saud University for funding this work through research group NO. RG-1441-384.

Institutional Review Board Statement: The study was conducted according to the guidelines of the Declaration of Helsinki, and approved by the Institutional Review Board (or Ethics Committee) of Riyadh Elm University (RC/IRB/2018/1227).

Informed Consent Statement: Informed consent was obtained from all subjects involved in the study.

Data Availability Statement: All the data is provided in the manuscript.

Acknowledgments: The authors extend their appreciation to the Deanship of Scientific Research at King Saud University for funding this work through research group NO. RG-1441-384.

Conflicts of Interest: The authors disclose no potential conflict of interest.

\section{References}

1. Ben-Amar, A.; Kaffe, I.; Gorfil, C. Marginal leakage in amalgam restorations and its prevention. Refu'at Ha-Peh Veha-Shinayim (Tel Aviv Isr. 1969) 1978, 27, 25-29.

2. Swift, E.J. Dentin/enamel adhesives: Review of the literature. Pediatr. Dent. 2002, 24, 456-461.

3. Swift, E.J.; Perdigão, J.; Heymann, H.O. Bonding to enamel and dentin: A brief history and state of the art, 1995. Quintessence Int. Engl. Ed. 1995, 26, 95-110.

4. Salerno, M.; Loria, P.; Matarazzo, G.; Tomè, F.; Diaspro, A.; Eggenhöffner, R. Surface morphology and tooth adhesion of a novel nanostructured dental restorative composite. Materials 2016, 9, 203. [CrossRef]

5. Bektas, O.O.; Eren, D.; Akin, E.G.; Akin, H. Evaluation of a self-adhering flowable composite in terms of micro-shear bond strength and microleakage. Acta Odontol. Scand. 2012, 71, 541-546. [CrossRef]

6. Labella, R.; Lambrechts, P.; Van Meerbeek, B.; Vanherle, G. Polymerization shrinkage and elasticity of flowable composites and filled adhesives. Dent. Mater. 1999, 15, 128-137. [CrossRef]

7. Sofan, E.; Sofan, A.; Palaia, G.; Tenore, G.; Romeo, U.; Migliau, G. Classification review of dental adhesive systems: From the IV generation to the universal type. Ann. Stomatol. 2017, 8, 1.

8. Vasconcelos e Cruz, J.; Polido, M.; Brito, J.; Gonçalves, L.L. Dentin bonding and SEM analysis of a new experimental universal adhesive system containing a dendrimer. Polymers 2020, 12, 461. [CrossRef]

9. Kaptan A, K.V.; Hürmüzlü, F.; Serper, A.; Kaptan, A. Effect of chemical irrigants on the bond strength of a universal adhesive system to dentin-enamel junction and different dentin regions. Clin. Med. Rev. Case Rep. 2019, 6, 285.

10. Nagarkar, S.; Theis-Mahon, N.; Perdigão, J. Universal dental adhesives: Current status, laboratory testing, and clinical performance. J. Biomed. Mater. Res. Part B Appl. Biomater. 2019, 107, 2121-2131. [CrossRef]

11. Unterbrink, G.L.; Liebenberg, W.H. Flowable resin composites as "filled adhesives": Literature review and clinical recommendations. Quintessence Int. 1999, 30, 249-257.

12. Korkmaz, Y.; Gurgan, S.; Firat, E.; Nathanson, D. Shear bond strength of three different nano-restorative materials to dentin. Oper. Dent. 2010, 35, 50-57. [CrossRef]

13. Goracci, C.; Cadenaro, M.; Fontanive, L.; Giangrosso, G.; Juloski, J.; Vichi, A.; Ferrari, M. Polymerization efficiency and flexural strength of low-stress restorative composites. Dent. Mater. 2014, 30, 688-694. [CrossRef] [PubMed]

14. Sudsangiam, S.; Van Noort, R. Do dentin bond strength tests serve a useful purpose? J. Adhes Dent. 1999, 1, 57-67. [PubMed]

15. Ferdianakis, K. Microleakage reduction from newer esthetic restorative materials in permanent molars. J. Clin. Pediatr. Dent. 1998, 22, 221-229. [PubMed]

16. Ikeda, M.; Tsubota, K.; Takamizawa, T.; Yoshida, T.; Miyazaki, M.; Platt, J.A. Bonding durability of single-step adhesives to previously acid-etched dentin. Oper. Dent. 2008, 33, 702-709. [CrossRef]

17. Van Meerbeek, B.; Van Landuyt, K.; De Munck, J.; Hashimoto, M.; Peumans, M.; Lambrechts, P.; Yoshida, Y.; Inoue, S.; Suzuki, K. Technique-sensitivity of contemporary adhesives. Dent. Mater. J. 2005, 24, 1-13. [CrossRef]

18. Vichi, A.; Margvelashvili, M.; Goracci, C.; Papacchini, F.; Ferrari, M. Bonding and sealing ability of a new self-adhering flowable composite resin in class I restorations. Clin. Oral Investig. 2012, 17, 1497-1506. [CrossRef] [PubMed] 
19. Naughton, W.T.; Latta, M.A. Bond strength of composite to dentin using self-etching adhesive systems. Quintessence Int. 2005, 36, 259-262.

20. Singh, K.; Naik, R.; Hegde, S.; Damda, A. Shear bond strength of superficial, intermediate and deep dentin in vitro with recent generation self-etching primers and single nano composite resin. J. Int. Oral Health 2015, 7, 28-32.

21. Poitevin, A.; De Munck, J.; Van Ende, A.; Suyama, Y.; Mine, A.; Peumans, M.; Van Meerbeek, B. Bonding effectiveness of self-adhesive composites to dentin and enamel. Dent. Mater. 2013, 29, 221-230. [CrossRef]

22. Wajdowicz, M.N.; Vandewalle, K.S.; Means, M.T. Shear bond strength of new self-adhesive flowable composite resins. Gen. Dent. 2012, 60, 104-108.

23. Giannini, M.; Makishi, P.; Ayres, A.P.A.; Vermelho, P.M.; Fronza, B.M.; Nikaido, T.; Tagami, J. Self-etch adhesive systems: A literature review. Braz. Dent. J. 2015, 26, 3-10. [CrossRef] [PubMed]

24. Altunsoy, M.; Tanriver, M.; Ok, E.; Kucukyilmaz, E. Shear bond strength of a self-adhering flowable composite and a flowable base composite to mineral trioxide aggregate, calcium-enriched mixture cement, and biodentine. J. Endod. 2015, 41, 1691-1695. [CrossRef] [PubMed]

25. Yousef, M.K.; El Naga, A.A.; Ramadan, R.; Fayez, C.; Alshawwa, L.; Bahgat, S.F. Does the use of a novel self-adhesive flowable composite reduce nanoleakage? Clin. Cosmet. Investig. Dent. 2015, 7, 55-64. [CrossRef]

26. Makishi, P.; Pacheco, R.R.; Sadr, A.; Shimada, Y.; Sumi, Y.; Tagami, J.; Giannini, M. Assessment of self-adhesive resin composites: Nondestructive imaging of resin-dentin interfacial adaptation and shear bond strength. Microsc. Microanal. 2015, 21, 1523-1529. [CrossRef]

27. Salerno, M.; Derchi, G.; Thorat, S.; Ceseracciu, L.; Ruffilli, R.; Barone, A.C. Surface morphology and mechanical properties of new-generation flowable resin composites for dental restoration. Dent. Mater. 2011, 27, 1221-1228. [CrossRef]

28. Arlin, K.; Filiz, Y.; Saadet, G. Bonding to enamel and dentin using self-etching adhesive systems. Quintessence Int. 2004, 35, 367-370.

29. Bhandary, S.; Hegde, M.N. An evaluation and comparison of shear bond strength of composite resin to dentin, using newer dentin bonding agents. J. Conserv. Dent. 2008, 11, 71-75. [CrossRef] [PubMed]

30. Thorat, S.B.; Diaspro, A.; Salerno, M. In vitro investigation of coupling-agent-free dental restorative composite based on nanoporous alumina fillers. J. Dent. 2014, 42, 279-286. [CrossRef] [PubMed]

31. Goracci, C.; Margvelashvili, M.; Giovannetti, A.; Vichi, A.; Ferrari, M. Shear bond strength of orthodontic brackets bonded with a new self-adhering flowable resin composite. Clin. Oral Investig. 2012, 17, 609-617. [CrossRef]

32. Viotti, R.G.; Kasaz, A.; Peña, C.E.; Alexandre, R.S.; Arrais, C.A.; Reis, A.F. Microtensile bond strength of new self-adhesive luting agents and conventional multistep systems. J. Prosthet. Dent. 2009, 102, 306-312. [CrossRef]

33. Goracci, C.; Sadek, F.; Fabianelli, A.; Tay, F.; Ferrari, M. Evaluation of the adhesion of fiber posts to intraradicular dentin. Oper. Dent.-Univ. Wash. 2005, 30, 627.

34. Monticelli, F.; Osorio, R.; Mazzitelli, C.; Ferrari, M.; Toledano, M. Limited decalcification/diffusion of self-adhesive cements into dentin. J. Dent. Res. 2008, 87, 974-979. [CrossRef] [PubMed]

35. Gerth, H.U.; Dammaschke, T.; Züchner, H.; Schäfer, E. Chemical analysis and bonding reaction of RelyX Unicem and Bifix composites-a comparative study. Dent. Mater. 2006, 22, 934-941. [CrossRef]

36. Tuloglu, N.; Tunç, E.S.; Ozer, S.; Bayrak, S. Shear bond strength of self-adhering flowable composite on dentin with and without application of an adhesive system. J. Appl. Biomater. Funct. Mater. 2013, 12, 97-101. [CrossRef]

37. Asmussen, E.; Uno, S. Solubility parameters, fractional polarities, and bond strengths of some intermediary resins used in dentin bonding. J. Dent. Res. 1993, 72, 558-565. [CrossRef]

38. Miller, R.G.; Bowles, C.Q.; Chappelow, C.C.; Eick, J.D. Application of solubility parameter theory to dentin-bonding systems and adhesive strength correlations. J. Biomed. Mater. Res. 1998, 41, 237-243. [CrossRef]

39. Pacifici, E.; Chazine, M.; Vichi, A.; Grandini, S.; Goracci, C.; Ferrari, M. Shear-bond strength of a new self-adhering flowable restorative material to dentin of primary molars. J. Clin. Pediatr. Dent. 2013, 38, 149-154. [CrossRef]

40. Juloski, J.; Goracci, C.; Rengo, C.; Giovannetti, A.; Vichi, A.; Vulicevic, Z.R.; Ferrari, M. Enamel and dentin bond strength of new simplified adhesive materials with and without preliminary phosphoric acid-etching. Am. J. Dent. 2012, 25, $239-243$.

41. Titley, K.C.; Chernecky, R.; Rossouw, P.E.; Kulkarni, G.V. The effect of various storage methods and media on shear-bond strengths of dental composite resin to bovine dentine. Arch. Oral Biol. 1998, 43, 305-311. [CrossRef]

42. Al-Salehi, S.K.; Burke, F.J. Methods used in dentin bonding tests: An analysis of 50 investigations on bond strength. Quintessence Int. 1997, 28, 717-723. [PubMed]

43. Sakaguchi, R.L.; Powers, J.M. Chapter 5-Testing of Dental Materials and Biomechanics. In Craig's Restorative Dental Materials, 13th ed.; Mosby: Saint Louis, MI, USA, 2012; pp. 83-107. 